\title{
The Fifth Washington Meeting of the American Association for the Advancement of Science.
}

THE fifth Washington meeting of the American Association for the Advancement of Science was held during convocation week, December 29, 1924-January 3, I925. This meeting was one of the larger, quadrennial meetings, which are regularly held in Washington, New York, and Chicago, and it surpassed all earlier meetings of the Association in the number registered as in attendance. The registration figures for the last five meetings are as follows: Chicago (I92I) 24I3; Toronto (I92I) I832; Boston (I922) 2339; Cincinnati (1924) 22II ; Washington (I925) 4206

The fifteen sections of the Association were well represented, and 36 associated societies, of which 24 are affiliated, met with the sections of the Association. Eleven other scientific organisations met with the Association by invitation. Altogether 252 scientific sessions were held, as well as a large number of business sessions, dinners, etc. The total number of papers and addresses at Washington was about r7xo.

Washington has more scientific workers in proportion to its population than any other city of the country. It has numerous institutions and organisations devoted to scientific research and to the spread of scientific knowledge. The George Washington University, the National Geographic Society, the many government scientific bureaux and offices, the Smithsonian Institution, the Carnegie Institution of Washington, the National Academy of Sciences, and the National Research Council are all of Washington, and all took active part in the arrangements for this meeting. The quarters of many of these organisations were made available for section and society sessions, and the Central High School building was secured for a large group of the sessions.

The exhibition for this meeting was exceptionally well developed, and offered many unusual opportunities for the actual inspection of apparatus, materials, and facilities for research and teaching, as well as newly developed scientific methods and recent publications. The general exhibition was the most complete and representative exhibition held by the Association in recent years. Fifty business firms that supply scientific instruments and materials, and publishers of scientific books, took part, and a large number of individual men of science exhibited new research methods and instruments. Special exhibitions by Washington scientific organisations formed an attractive feature this year. The annual exhibition of recent scientific work of the Carnegie Institution of Washington was specially maintained for this meeting. The new building of the National Academy of Sciences and the National Research Council, which is accounted the finest of its kind in the world, was open for inspection daily ; a very attractive and inspiring permanent exhibition of scientific principles and methods was displayed in this new "Temple of American Science." Many of the offices and laboratories of the United States Department of Agriculture were open to visiting scientific workers. The U.S. Bureau of Standards, the New National Museum, the Old National Museum, the Smithsonian Institution building, and the Freer Art Gallery were also open for inspection. Exhibitions by scientific societies that took part in the meeting were arranged; these were generally of special interest to workers in the fields represented by the societies, and contained exhibits of research methods and apparatus shown by their originators.

With a rapidly increasing public interest in scientific knowledge, the recent annual meetings of the NO. 2894 , VOL. I I 5$]$
American Association have received a progressively greater share of attention on the part of the daily press. One of the chief aims of the Association is to further the appreciation of science and the work of scientific men, and it has rapidly improved its publicity service in recent years. This service now constitutes a very important feature of each annual meeting. It aims at furnishing to the newspapers throughout the country interesting and trustworthy items from the various scientific programmes. The Publicity Committee was very efficiently helped by the co-operation of Science Service, which furnishes science news to a series of subscribing newspapers. For the first time in the history of the American Association, radio was used as an integral part of the publicity service. The two large stations in Washington broadcasted talks given by well-known scientific men whose influence on the upbuilding of science is generally recognised. The territory covered by the two stations is very wide, responses from their programmes having been received from Hudson Bay, Seattle, San Francisco, Long Beach, Los Angeles, Honduras, San Salvador, Cuba, and Haiti. Through radio talks, a vast number of people were reached who are deeply interested in the acquisition of scientific knowledge but unfamiliar with the channels through which accurate information may be obtained. The great value of thus broadening the contacts of the annual meetings of the Association and of stimulating a wider interest in and appreciation for scientific work can scarcely be overestimated.

Eight general sessions of the Association were held at Washington. The opening session occurred on Monday evening, December 29, in the Memorial Continental Hall. This session was addressed by the Honourable Charles Evans Hughes, Secretary of State, who spoke on "Some Aspects of International Co-operation." At this session was delivered the address of the retiring president of the Association, Dr. Charles D. Walcott, secretary of the Smithsonian Institution. The subject of Dr. Walcott's address was "Science and Service." Following the opening session, there was a general reception given by the local Association members. The reception was held in the New National Museum.

The second general session was held on Tuesday afternoon, December 30. The speaker at this session was Mr. Austin H. Clark, of the Smithsonian Institution, member of the Navy Department's Advisory Committee on Oceanography. Mr. Clark's subject was " The Navy's Oceanographic Program."

The third general session was held on Tuesday evening, December 30 . This session was devoted to the third annual Sigma Xi lecture, held under the joint auspices of the Association and the Society of Sigma Xi. The lecture this year was by Dr. Frederick Fuller Russell, general director of the International Health Board, whose subject was " War on Diseases, with Special Reference to Malaria and Yellow Fever."

The fourth general session occurred on Wednesday afternoon, December 3r. At this general session Dr. Charles D. Walcott gave a beautifully illustrated lecture of general interest on " Geological Exploration in the Canadian Rockies."

The fifth general session was held on Wednesday evening, December 3r. A fine series of motion pictures, taken on the western excursion that succeeded the recent Toronto meeting of the British Association, was shown at this session. Dr. Edwin E. Slosson, director of Science Service, who took part in the trip, spoke. These films were very kindly loaned for this showing by the Provincial Motion Picture Bureau 
of Ontario, Canada. Many striking and beautiful Canadian views were seen, and a number of eminent British scientific workers appeared in the pictures.

The sixth general session was held on Thursday afternoon, January x. Prof. A. E. Douglass, director of the Observatory of the University of Arizona, spoke on the "University of Arizona Eclipse Expedition of September I923," and showed beautifully coloured lantern slides. Besides its contribution of astronomical knowledge presented in an easily understood style, this lecture also presented something of desert adventure that did not fail to attract attention.

The seventh general session occurred on Thursday evening, January I. Dr. Willis T. Lee, of the United States Geological Survey, gave a lecture at this session, on "Explorations in the Carlsbad Caverns of New Mexico." The studies reported were carried out under the auspices of the National Geographic Society. Dr. Lee's illustrations included motion pictures secured by means of flares in these very interesting caves.

The eighth general session was held on Friday afternoon, January 2. Motion picture films illustrating the principles and operation of the telephone, human speech, etc., were given their first public showing, and an explanatory talk was given by Dr. John Mills, of the Western Electric Company of New York City.

The following is a list of the vice-presidential (sectional) addresses delivered at Washington; they are being published in full in Science:-Section A (Mathematics) - "The Foundations of the Theory of Algebraic Numbers." By Harris Hancock, University of Cincinnati. Section B (Physics) - " Trend of Thought in Physics." By W. F* G. Swann, Yale University. Section C (Chemistry)-_" Some Effects of the Atmosphere upon Physical Measurements." By E. W. Washburn, National Research Council, Washington, D.C. Section D (Astronomy)-“"The Equinox of 1950." By Heber D. Curtis, Allegheny Observatory, Pittsburg, $\mathrm{Pa}$. Section E (Geology and Geography) - " A Classification of Natural Resources." By N. M. Fenneman, University of Cincinnati. Section F (Zoological Sciences) - "Darwin and Bryan: a Study in Method." By Edward L. Rice, Ohio Wesleyan University, Delaware, Ohio. Section G (Botanical Sciences) - "The Origin of the Cycads." By C. J. Chamberlain, University of Chicago. Section $\mathrm{K}$ (Social and Economic Sciences) - "The Development of Modern Family Life." By John Franklin Crowell. Section L (Historical and Philological Sciences) - "Leibnitz, The Master Builder of Mathematical Notations."' By Florian Cajori, University of California. Section N (Medical Sciences) - "The Relation of Certain Free Living Micro-Organisms to Disease." By Richard P, Strong, Harvard University. Section O (Agriculture) - " Better Adapting our Educational and Investigational Efforts to the Agricultural Situation." By R. A. Pearson, Iowa State College. Section Q (Education) - "The New Social Order as seen from the Standpoint of Education." By Henry W. Holmes, Harvard University.

The Council of the Association met on various occasions during the meeting for the transaction of business, some items of which are of general interest.

Under the provisions of the Jane M. Smith Fund, the following three members were elected to emeritus life membership of the Association: Ira Remsen, Johns Hopkins University; E. S. Dana, 24 Hillhouse Ave., New Haven, Conn. ; H. C. Yarrow, 8I4-ryth St., N.W., Washington, D.C.

The sum of 3000 dollars was appropriated for grants for research in 1925 , to be allotted by the Committee on Grants and disbursed from the available funds of the treasurer's office. The Council appropriated 500 dollars as a temporary aid to the Union of American Biological Societies in its project for Biological Abstracts. It was decided that the annual meeting of December I927 shall he held in Nashville, Tennessee.

Prof. Michael Pupin, professor of physics in Columbia University, New York, was elected president of the Association. The following vice-presidents (chairmen of sections) and secretaries of sections were also elected :-Section A : W. A. Roever, professor of mathematics, Washington University, St. Louis; R. C. Archibald, associate professor of mathematics, Brown University, Providence, R.I. Section $B$ : H. M. Randall, professor of physics, University of Michigan; A. L. Hughes, Washington University, St. Louis, Mo. Section C: H. B. Cady, professor of chemistry, University of Kansas ; Gerald Dietrichson, University of Illinois, Urbana, Illinois. Section $D$ : A. E. Douglass, professor of astronomy, University of Arizona; Philip Fox, professor of astronomy, Northwestern University, Evanston, IIl. Section $E$ : R. A. Daly, professor of geology, Harvard University; G. R. Mansfield, U.S. Geological Survey, Washington, D.C. Section F: H. S. Jennings, professor of zoology, Johns Hopkins University; G. T. Hargitt, professor of zoology, Syracuse University, Syracuse, N.Y. Section G: R. B.'Wylie, professor of botany, Iowa State University; S. F. Trelease, professor of plant physiology, University of Louisville, Louisville, Ky. Section H: C. B. Davenport, director of the Station for Experimental Evolution, Carnegie Institution of Washington; R. J. Terry, professor of anatomy, Washington School of Medicine, St. Louis, Mo. Section I : C. E. Seashore, professor of psychology, Iowa State University; F. N. Freeman, professor of physiology, University of Chicago, Chicago, I11. Section $K:$ F. R. Fairchild, professor of political economy, University; F. L. Hoffman, Babson Institute, Babson Park, Mass. Section L: W. A. Oldfather, professor of classics, University of Illinois; F. E. Brason, Congressional Library, Smithsonian Division, Washington, D.C. Section $M:$ F. G. Cottrell, director of the Fixed Nitrogen Laboratory, U.S. Department of Agriculture; N. H. Heck, U.S. Coast and Geodetic Survey, Department of Commerce, Washington, D.C. Section N: A. J. Carlson, professor of physiology, University of Chicago; A. J. Goldfarb, professor of biology, College of the City of New York, New York, N.Y. Section O : C. V. Piper, agrostologist, U.S. Department of Agriculture; P. E. Brown, Iowa State College, Ames, Iowa. Section $Q$ : O. W. Caldwell, director of the Lincoln School, Columbia University; A. S. Barr, University of Wisconsin, Madison, Wis.

Other officers are: Permanent Secretary: Burton E. Livingston, director of the Laboratory of Plant Physiology, Johns Hopkins University, Baltimore, Maryland. General Secretary: W. J. Humphreys, professor of meteorology, George Washington University and U.S. Weather Bureau, Washington, D.C. Treasurer: J. L. Wirt, Carnegie Institution of Washington, Washington, D.C. Elected Members of Council: Dr. L. O. Howard, Chief of the Bureau of Entomology, U.S. Department of Agriculture, Washington, D.C. ; Dr. D. T. MacDougal, director of the Desert Laboratory, Carnegie Institution of Washington, Tucson, Arizona. Elected Members of the Executive Committee: B. M. Duggar (1925), Missouri Botanical Garden, St. Louis, Mo. ; Edwin B. Wilson (1928), Massachusetts Institute of Technology, Cambridge, Mass. ; Vernon L. Kellogg (1928), permanent secretary of the National Research Council, Washington, D.C. 